\title{
Public Private Partnerships as a Systemic Instrument of Governance in Regional Innovation Policy
}

\author{
Iryna Kristensen \\ Nordic Center for Spatial Development, Stockholm, Sweden \\ iryna.kristensen@nordregio.se \\ Walter Scherrer \\ University of Salzburg, Department of Economics, Salzburg, Austria \\ walter.scherrer@sbg.ac.at
}

\section{ABSTRACT}

\begin{abstract}
We discuss which systemic functions can be implemented in regional innovation systems by using public private partnerships (PPP) as a vehicle of governance in innovation policy. We analyze PPPs in the field of regional innovation policy in which Swedish municipalities and regional authorities have been involved. We find that such PPPs are able to address knowledge related systemic goals of regional innovation policy more comprehensively than entrepreneurial goals; that PPPs tend to address the quantitative dimensions of systemic goals of regional innovation policy better than qualitative dimensions; and that there is considerable variation how PPPs address innovation-related goals across types of regions and industries involved.
\end{abstract}

Keywords: public-private partnerships, regional innovation systems, systemic instrument of regional innovation policy, regional governance

JEL: O38, R59

\section{Introduction}

Public-private partnerships (PPPs) have appeared as an "emerging (and preferred) instrument" of governance in regional innovation policy, particularly in research and development policies and in cluster policies (Karlsson, 2008; OECD, 2011), with a focus on building and strengthening interfaces between the actors of a regional innovation system (Cooke \& Morgan, 1994; Fogelberg \& Thorpenberg, 2012; Hagedoorn, Link, \& Vonortas, 2000; OECD, 2004, 2010, 2011). From a systemic perspective, the increased heterogeneity of innovation processes has, on the one hand, intensified networking and interactive learning as necessary provisions for promoting and diffusing innovation within a region (Asheim, Smith \& Oughton, 2011; 
Lundvall, 1992; OECD, 2011), but on the other hand, it has significantly elevated coordination needs and the risk of systemic failure (Smits \& Kuhlmann, 2004; Wieczorek \& Hekkert, 2012).

While most studies of regional innovation systems (RIS) focus on dynamics and innovation performance of RIS agents to provide inputs for innovation policy, our study addresses a key governance issue by analyzing established cooperative practices between public and private sector actors from a systemic perspective. The merge of structural facets that "produce, distribute and apply various kinds of knowledge" significantly facilitates knowledge generation (Wolfe, 1999, p. 130) and PPPs by its very nature are capable of acting as a systemic policy instrument to enhance interface management, strengthen cross-sectoral linkages and stimulate demand for goods based on specific technologies. Therefore, the concept of PPP - on which this paper is based - is defined in terms of synergetic relations between innovation agents, and is expressed in a co-operative institutional arrangement (Hodge \& Greve, 2007).

We hypothesize that PPP is a suitable policy instrument to address systemic goals of regional innovation policy (RIP) and stimulate knowledgedevelopment and entrepreneurial activities within an RIS. Our analysis of six RIP-related PPPs in Sweden largely confirms these hypotheses. The paper is organized as follows: Section 2 outlines the conceptual framework; Section 3 presents the research design and gives an overview of the empirical basis. Systemic goals addressed by PPPs are highlighted in Sections 4 (with regard to knowledge-related activities) and 5 (with regard to entrepreneurial activities). Section 6 provides conclusions.

\section{The Conceptual Framework}

\subsection{Systemic Problems in Regional Innovation Systems}

A regional innovation system (RIS) can be defined as an "institutional infrastructure supporting innovation within the productive structure of a region" (Asheim \& Coenen, 2005) that comprises the knowledge application and exploitation sub-systems (regional production structure) and the knowledge generation and diffusion sub-systems (regional supportive infrastructure) (Cooke, 2002). Schumpeterian "new combinations" or crossfertilization of existing factors are generated by a multifaceted set of structures in a different way (Lundvall, 1992), and innovation is considered an endogenous process comprising multiple learning processes embedded in regular economic activities (Edquist, 1997). The RIS approach emphasizes actors' interdependence in the process of knowledge production, the institutional context that facilitates interaction and collective learning, and the position that tacit and "sticky" knowledge is best "traded" in a shared social milieu (Asheim \& Coenen, 2005; Edquist, 1997; Gertler, 2003; Isaksen, 2001). 
The systemic dimension of RIS derives from synergetic effects generated in the interaction among economic demand, political objectives, and technological opportunities (Leydesdorff \& Zawdie, 2010), and the performance of an RIS therefore depends on the appropriate institutional milieu and the dynamics of actors' interactions. The increased importance of nonmarket coordination due to the systemic nature of innovation, and the integration of national and global markets into more complex systems has awakened interest for innovation policy instruments which are capable of handling interfaces and addressing enhanced coordination needs (Galli \& Teubal, 2002).

Conceptual requirements of policy tools for dealing with systemic failures have been developed by Smits \& Kuhlmann (2004) and Wieczorek \& Hekkert (2012); the latter distinguish four systemic problems of the innovation process:

1. actors' problems are related to the (non-) presence of key actors (companies, knowledge organizations, government and others like financial organizations) and the (non-) availability of appropriate competences to face technological changes;

2. interaction/network problems are related to technological lockins hampering the development of new technologies, to the lack of complementary capabilities between agents, and to the level of interaction intensity (which might be too weak or too strong);

3. institutional problems are linked to "common sets of habits, routines, established practices, rules, or laws that regulate the relations and interactions between individuals, groups and organisations" (Edquist \& Johnson, 1997) which might be inadequate for supporting innovation;

4. infrastructural problems are related to the availability and quality of physical infrastructure (including networks), knowledge/scientific infrastructure, and financial infrastructure.

Addressing these systemic problems requires policy instruments that potentially focus on the innovation system as a whole, supporting thereby crucial elements in the governance of innovation processes. Therefore systemic instruments are specific interventions that ought to target relevant system imperfections and failures, namely (Wieczorek \& Hekkert, 2012):

1. the presence of actors' problems is addressed through the goal to "Stimulate and organize the participation of relevant actors" (henceforth: systemic goal $A$ ), and the capabilities' dimension of actors' problems through the goal to "Create space for actors' capabilities development" (goal $B)$;

2. the presence of interaction problems is addressed through the goal to "Stimulate occurrence of interaction among heterogeneous actors" (goal $C$ ), and the capacity aspect of interaction problems through the goal to "Prevent ties that are either too strong or too weak" (goal $D$ ); 
3. the presence of institutional problems is addressed through the goal to "Secure presence of hard and soft institutions" (goal $E$ ), the intensity dimension of institutional problems through the goal to "Prevent institutions being too weak or too stringent" (goal F);

4. the presence of infrastructural problems is addressed through the goal to "Stimulate physical, financial and knowledge infrastructure" (goal $G$ ), and the quality aspect of infrastructural problems through the goal to "Ensure adequate quality of infrastructure" (goal $H$ ).

Hence each category of systemic innovation problems comprises a quantitative dimension (presence of the problem) and a qualitative dimension (quality/intensity of the problem). In addition, each category also comprises an entrepreneurial dimension and a knowledge-related dimension for stimulating innovation'. For allowing technological innovation activity to unfold its potential, simultaneous changes should take place across sectors and organizations calling for dynamic interaction between various actors of the innovation process.

\subsection{Systemic Innovation Problems and PPP}

In a systemic view of innovation, PPPs' primary role is to build cooperation among agents involved in the innovation process and to build and strengthen the relationships between the public and private sectors. A PPP is

"an agreement between the government and one or more private partners (which may include the operators and the financers) according to which the private partners deliver the service in such a manner that the service delivery objectives of the government are aligned with the profit objectives of the private partners and where the effectiveness of the alignment depends on a sufficient transfer of risk to the private partners" (OECD, 2008).

While many studies of PPP emphasize macroeconomic or microeconomic motivations for applying PPPs in public infrastructure development (e.g. Mrak, 2006; McQuaid \& Scherrer, 2008; Švigelj \& Hrovatin, 2013) in the case of innovation-policy delivery, PPPs are specifically motivated by their capacity to coordinate public and private actors (McQuaid \& Scherrer, 2010; Kristensen, McQuaid, \& Scherrer, 2016). Consequently, by their very nature PPPs enable policy makers to address systemic goals of innovation policy and to correct for systemic failures. PPP as a mode of governance then serves as a systemic instrument of innovation policy connecting public and private agents in a way which allows them to search for new combinations of factors of production, share risks and, finally, deliver a new product or service. ${ }^{2}$ As the underlying rationale for collaboration in knowledge-related activities rests mainly on exploiting diverse knowledge, PPPs potentially encourage non-profit and

1 Therefore subscript $k$ will be used for knowledge-related systemic goals and subscript $e$ for entrepreneurial systemic goals.

2 This paper has its focus on technological innovation and on related services which are delivered in collaboration between public and private partners. 
for-profit innovation agents to interact in a synergistic way (Edquist, 1997; Nelson \& Winter, 1977).

Therefore, we hypothesize (H1) that PPPs are able to ensure the presence of relevant structural elements needed for knowledge-related activities within RIS by creating platforms for knowledge and competence exchange; and ( $\mathrm{H} 2)$ that PPPs are able to address the quality of structural properties relevant for knowledge-related activities within RIS by creating and stimulating interactive continuous learning among system elements.

The knowledge development activities, constitute, however, just one dimension of RIS, as knowledge ought to be translated into revenuecreating commercial activities in order for innovation to happen. In a systemic perspective of innovation not all aspects of knowledge generation and diffusion can be explained with the "isolated profit-maximizing firm" (Edquist, 1997) since the behavior and interaction of many RIS elements are governed by non-market forces (Edquist, 1997; Nelson \& Winter, 1977). The capabilities and resources required for dealing with "the interconnected issues raised in many policy areas" (McQuaid, 2000) reside only partially within any given innovation agent. From a systemic perspective, entrepreneurs are seen as social agents that learn by interacting and develop their entrepreneurial identities only within an appropriate supporting system because interdependence shapes and limits the innovative capabilities and competitive dynamics of local companies. Hence, innovation actors should seek collaboration with partners that have a competitive advantage in particular aspects of an entrepreneurial ecosystem. Collaboration is best achieved in the context of shared accountability and commitment where all partners have an opportunity to influence the shared objectives, outcomes, evaluations and decision-making processes (Brinkerhoff \& Brinkerhoff, 2011). However, cooperation among local agents and the entrepreneurial climate largely depend on the policy environment and the historical evolution of the regional institutional framework. Forming partnerships between public and private actors in RIS might help create a greater impact on policy choices and expand public support, increasing the legitimacy of actions and involving agencies with a more narrow range of objectives (McQuaid, 2000), thus allowing more targeted policy interventions (Silva \& Rodriguez, 2005).

Therefore we hypothesize (H3) that PPPs are able to ensure the presence of relevant structural elements needed for entrepreneurial activities within RIS; and $(\mathrm{H} 4)$ that PPPs are able to contribute to the entrepreneurial capacity of RIS by increasing the socio-institutional and innovative potential of public and (particularly) private actors involved in collaboration. 


\section{Research Design}

In order to empirically test the hypotheses $\mathrm{H} 1$ to $\mathrm{H} 4$ we adapt the systemic innovation policy framework of Wieczorek and Hekkert (2012) to six PPP cases which have been established in Sweden in the field of RIP ${ }^{3}$. Hypotheses will be considered confirmed if empirical results are supportive for all relevant goals in all six cases of PPP and will be considered rejected if empirical results are supportive only in two or fewer goals within a dimension (across all cases), and/or in three or fewer cases (across all goals within a dimension). Otherwise empirical results are considered only partially supportive.

Sweden was selected because of its long corporatist tradition in which public and private agents are expected to engage in cooperation for "the mutual benefit of social development" and because PPP as the "mutual development model in Sweden still worked" (Fogelberg \& Thorpenberg, 2012, p. 354). Empirical evidence suggests that PPPs are a common instrument in Sweden's RIP (Kristensen, McQuaid, \& Scherrer, 2016) rooted in strong local selfgovernance which enables local policy makers to exert a significant degree of autonomy in undertaking policy initiatives with the involvement of private partners (Weihe et al., 2011). Local policy makers enjoy considerable fiscal autonomy as the taxes on the local level account for two-thirds of Swedish local authorities' revenues and therefore provide a sound financial basis for a custom-tailored RIP (SCB, 2012).

For empirical analysis six PPPs from Övre Norrland (SE 33) and Sydsverige (SE 22) in the life science, ICT and automotive industries were selected. In order to capture regional and industry-specific variations, the case study selection criteria were based on innovative performance of the region ${ }^{4}$, the role of key knowledge-intensive industries for economic diversification of the region, and the co-initiation structure used for establishing the PPPs ${ }^{5}$. Semistructured interviews with major stakeholders of the PPPs constitute the major source of data; additional input was obtained through secondary data analysis covering evaluation reports, policy documents, legislation and other written material.

Interviews were conducted with six representatives from private companies (mainly chief-executive officers) and ten from the public sector including university researchers and representatives from national and regional governmental agencies. Interviews were based on open-ended and followup questions, enabling respondents to provide in-depth information on their experiences in public-private cooperation. Interview transcripts were coded according to categories and sub-categories identified in the course of data

3 For detailed information about the six cases see Appendix 1.

4 According to the European Regional Innovation Scoreboard (EU, 2014) Sydsverige (SE22, the South of Sweden) is an "innovation leader" region while Övre Norrland is an "innovation follower".

5 PPPs can be (co-) initiated by policy makers at the municipal and/or regional and/or national levels. 
processing (Saldaña, 2009), which are used as "proxies" for indicating if a PPP is considered to address the respective systemic goal (see Table 1).

Table 1: Definition of Proxy "Indicators"

\begin{tabular}{|c|c|c|}
\hline $\begin{array}{l}\text { RIS } \\
\text { dimension }\end{array}$ & $\begin{array}{l}\text { Systemic Goals } \\
k \text { : knowledge-related; } \\
e \text { : entrepreneurial }\end{array}$ & $\begin{array}{l}\text { Proxies } \\
k \text { : knowledge-related; } \\
e \text { : entrepreneurial }\end{array}$ \\
\hline \multirow[t]{4}{*}{ Presence } & $\begin{array}{l}A_{k}, A_{e} \text { "Stimulate and organise } \\
\text { the participation of relevant } \\
\text { actors" }\end{array}$ & $\begin{array}{l}\text { Learning-oriented meetings (for goal } A_{k} \text { ) } \\
\text { Existence of strategy-oriented meetings (for goal } A_{e} \text { ) }\end{array}$ \\
\hline & $\begin{array}{l}C_{k}, C_{e} \text { "Stimulate occurrence } \\
\text { of interaction among } \\
\text { heterogeneous actors" }\end{array}$ & $\begin{array}{l}\text { Frequency of formal \& informal interactions (for goal } C_{k} \text { ) } \\
\text { Consensus building efficiency (for goal } C_{e} \text { ) }\end{array}$ \\
\hline & $\begin{array}{l}E_{k}, E_{e} \text { "Secure presence of hard } \\
\text { and soft institutions" }\end{array}$ & $\begin{array}{l}\text { Presence of an adequate institutional framework } \\
\text { (for goal } E_{k} \text { ) } \\
\text { Lobbying power (for goal } E_{e} \text { ) }\end{array}$ \\
\hline & $\begin{array}{l}G_{k}, G_{e} \text { "Stimulate physical, } \\
\text { financial and knowledge } \\
\text { infrastructure" }\end{array}$ & $\begin{array}{l}\text { Availability of research infrastructure (for goal } G_{k} \text { ) } \\
\text { Availability of local financial support, physical } \\
\text { infrastructure and local commuting systems (for goal } G_{e} \text { ) }\end{array}$ \\
\hline \multirow[t]{4}{*}{ Quality } & $\begin{array}{l}B_{k}, B_{e} \text { "Create space for actors' } \\
\text { capabilities development" }\end{array}$ & $\begin{array}{l}\text { Partners' learning outcomes (for goal } B_{k} \text { ) } \\
\left.\text { Approaches to strategic planning (for goal } B_{e}\right)\end{array}$ \\
\hline & $\begin{array}{l}D_{k}, D_{e} \text { "Prevent ties that are } \\
\text { either too strong or too weak" }\end{array}$ & $\begin{array}{l}\text { Power structure \& the balance of partners' influence } \\
\text { (for goal } D_{k} \text { ) } \\
\text { Power structure \& the balance of partners' influence } \\
\text { (for goal } D_{e} \text { ) }\end{array}$ \\
\hline & $\begin{array}{l}F_{k}, F_{e} \text { "Prevent institutions being } \\
\text { too weak or too stringent" }\end{array}$ & $\begin{array}{l}\text { Stringency of the partnership composition (for goal } F_{k} \text { ) } \\
\text { General legal frame (for goal } F_{e} \text { ) }\end{array}$ \\
\hline & $\begin{array}{l}H_{k}, H_{e} \text { "Ensure adequate quality } \\
\text { of infrastructure" }\end{array}$ & $\begin{array}{l}\text { Research quality \& partners' contribution to education \& } \\
\text { research (for goal } H_{k} \text { ) } \\
\text { PPPs' impact on regional policy-making (for goal } H_{e} \text { ) }\end{array}$ \\
\hline
\end{tabular}

The respondents' answers could be subject to some bias as they might be interested in claiming that "their" respective PPP is successful and thus deliver a rather positive view on cooperation. Another challenge of qualitative analysis has been the lack of operational and comparable quantitative success indicators. For these reasons a cross-check with independent reports of selected PPPs and other sources was performed, showing that respondents' answers seem to provide an adequate picture of collaboration.

\section{PPP and Knowledge-Related Systemic Functions}

PPP's aim to bring together key public and private actors (goal $A_{k}$ ) to achieve a mission that requires competence, knowledge and resources beyond what each agent possesses individually. The participation of various public and private partners is stimulated and organized through narrow-focused expert meetings and more general educational or training meetings.

In addressing systemic goal Bk PPPs aim at developing new skills or techniques and act as a catalyst creating a stimulating environment for interaction. They facilitate learning by creating new practices and opening up new opportunities to enhance the optimization of shared information and data among partners. The rationale for undertaking a PPP from a learning perspective varies among participating private partners: business activities and innovation strategies 
in IT PPPs seem to require proactive learning, whereas in the life-science industry the preferred learning modes of the private partners are consistent with those forms that are easily accommodated within an existing operational and innovation model of the respective companies (this can mean simple business transactions like renting space or equipment to other companies).

Concerning goal $C_{k}$ the structures of the six PPPs allow for widening the scope of actors' regular (social) interaction through formal meetings (at least two per year) and informal meetings among stakeholders (which are considered essential for knowledge exchange).

Systemic goal $D_{k}$ is approximated by the existence of one or very few partners which dominate the PPP's goal setting and performance. The power distribution between partners has implications on the supply of complementary knowledge essential for interactive learning and innovation; different forms and shifts of power distribution might reduce incentives for public and (particularly) private participation. The dominance of the public actors' interest might not affect the intensity of current cooperation but might have an impact in the long run.

By providing an institutional framework (goal $E_{k}$ ) in the form of contracts and documents (hard institutions) which set up the respective public-private cooperation, PPPs in all six cases ensure the presence of a permanent cooperation platform for operation and decision-making. Soft institutions are promoted by several PPPs by enhancing cohesive social structures and developing common norms and trust among partners. Trust is considered particularly valuable in situations when the interests and incentives of partners are not perfectly aligned because it supports knowledge exchanges that would not have been possible otherwise.

The stringency of institutions (goal $F_{k}$ ) is reflected in the rigidity of membership structures (rules for partners' appointment and resignation) and the corresponding degree of knowledge-sharing among partners. "Open" partnership structures provide flexibility to incorporate "external" expertise and skills which are essential for the PPP's activities, while "rigid" forms reduce the risks of coordination failure and information leakage by limiting new partners' appointment. PPPs in life science and automotive industries are characterized by relatively weak institutional configurations, while in the IT industry rapid changes in technology and frequent new product introductions seem to require a partnership structure potentially capable of averting information leakage and unwanted competitors' access to new knowledge created within the partnership.

Systemic goal $G_{k}$ is addressed in all cases by providing research platforms for knowledge and competence exchange. The presence of a university is perceived to be crucial for achieving this goal. 
The quality of knowledge infrastructure (goal $H_{k}$ ) is influenced by companies' active involvement in education and research with the purpose to stimulate the responsiveness of higher education to industry needs. This commitment takes various forms like adjunct professorships, guest lecturing, industrial internships and PhDs, student projects and supervision etc. Interaction between industry and academia is rather intense in all PPPs, and only in one case has the intensity of industry-university interaction decreased recently.

\section{PPP and Entrepreneurial Systemic Functions}

All six PPPs succeed in stimulating and organizing the participation of relevant actors (goal $A_{e}$ ) through strategic meetings and market-oriented activities like branding support. No specific regional tax incentives have been applied to stimulate private partners' participation in public-private cooperation for innovation creation.

By applying a team-based approach to the strategic planning of collaborative activities all PPPs provide an opportunity for partners to articulate available competences and resources (goal $B_{e}$ ). Only one PPP applies a few-player approach to strategic planning, in which private companies are not essentially involved in the process of vision and strategy development.

With regard to goal $C_{e}$ the IT-sector PPPs explicitly report that direct communication among partners significantly contributes to consensusbuilding through balancing interests, which might be attributed to their rigid organizational structure. Within the life-science sector PPPs' public and private partners achieve common ground by jointly pursuing long-term goals of regional growth and employment generation, while consensus-building processes appear to be less well articulated in automotive-industry PPPs. Among their members most PPPs enhance the perception of individual and collective benefits from knowledge- and competence-sharing among partners (which is consistent with goal $B_{e}$ ).

Systemic goal $D_{e}$ is addressed in the same way as concerning knowledgerelated activities. In one PPP in Sydsverige large private players show some dominance, while in one PPP in Övre Norrland regional and local authorities dominate.

Concerning goal $E_{e}$ differences across PPPs exist; they are systematically related neither to sectors nor to regions in which the PPPs have been established. Nearly all cases report only limited lobbying activity to take place through the PPP which suggests that such activities are either carried out through other channels (e.g. business and industry associations) or by large enterprises which are partners in the PPP but which can act independently.

Addressing systemic goal $F_{e}$ through PPPs seems to be sector-related. PPPs in the ICT sector, again, exhibit rigid membership structures whereas PPPs in the life-science and automotive industries have more flexible membership 
structures. Open PPP membership structures seem to be more important concerning entrepreneurial activities than knowledge-related activities.

All PPPs are successful in providing an extent of physical infrastructure (goal $G_{e}$ ) which is adequate to manage collaborative activities. The specific financial infrastructure in the form of joint research funding is provided in two PPPs, while infrastructure of a more general nature like public transport and logistics is provided outside the PPPs.

With regard to goal $H_{e}$ PPPs in the peripheral region are placed within relatively small (though active) regional research environments and considered important regional players. They are strongly involved in regional economic policy-making, considering this a major channel to ensure the provision of adequate infrastructure. PPPs in the larger and higher developed Sydsverige play a less important role in regional economic policy making.

\section{Summary and Conclusion}

The capacity of PPPs to address systemic goals and to act as a mode of governance in regional innovation policy was analyzed by applying a framework of systemic goals and functions of innovation policy developed by Wieczorek and Hekkert (2012) to six cases in Sweden. Four hypotheses on the capability of PPPs to provide systemic functions in RIP were developed in section 2 and were tested in sections 4 and $5^{6}$. Table 2 provides an overview of results; a " $\checkmark$ " indicates that a goal is addressed by the corresponding PPP case.

Hypothesis $\mathrm{H} 1$ is confirmed: PPPs appear to be important for stimulating the participation of multiple stakeholders (goal $A_{k}$ ), the occurrence of interactions among them (goal $C_{k}$ ), securing the presence of hard and soft institutions (goal $E_{k}$ ), and ensuring the availability of the knowledge infrastructure (goal $G_{k}$ ). PPPs therefore generally are capable of addressing the presence dimension of knowledge-related systemic functions of an RIS.

Hypothesis $\mathrm{H} 2$ is partially supported by empirical evidence: All PPPs aim at "direct learning" outcomes and act as a catalyst for creating a stimulating environment for interaction (goal $B_{k}$ ) and add to providing high-quality knowledge-related infrastructure for innovation (goal $H_{k}$ ). The stringency of linkages between public and private stakeholders (goal $F_{k}$ ) varies across economic sectors, and a majority of PPPs (though not all) extend partners' capacity to exert influence over the partnership's operating activities (goal $\left.D_{k}\right)$.

6 Hypotheses will be considered confirmed if empirical results are supportive for all relevant goals in all six cases of PPP and will be considered rejected if empirical results are supportive only in two or fewer goals within a dimension (across all cases), and/or in three or fewer cases (across all goals within a dimension). Otherwise empirical results are considered only partially supportive. See section 3. 
Public Private Partnerships as a Systemic Instrument of Governance in Regional Innovation Policy

Table 2: Knowledge-Related and Entrepreneurial Goals Addressed by PPP Cases - Overview

\begin{tabular}{|c|c|c|c|c|c|c|c|}
\hline \multirow[b]{2}{*}{ Hypothesis } & \multirow[b]{2}{*}{ Goal } & \multicolumn{6}{|c|}{ PPP cases } \\
\hline & & MV & $\mathrm{BU}$ & SoS & $\mathrm{FL}$ & KCFP & CASTT \\
\hline \multirow{4}{*}{$\mathrm{H} 1$} & Goal $A_{k}$ & $\checkmark$ & $\checkmark$ & $\checkmark$ & $\checkmark$ & $\checkmark$ & $\checkmark$ \\
\hline & Goal $C_{k}$ & $\checkmark$ & $\checkmark$ & $\checkmark$ & $\checkmark$ & $\checkmark$ & $\checkmark$ \\
\hline & Goal $E_{k}$ & $\checkmark$ & $\checkmark$ & $\checkmark$ & $\checkmark$ & $\checkmark$ & $\checkmark$ \\
\hline & Goal $G_{k}$ & $\checkmark$ & $\checkmark$ & $\checkmark$ & $\checkmark$ & $\checkmark$ & $\checkmark$ \\
\hline \multirow{4}{*}{$\mathrm{H} 2$} & Goal $B_{k}$ & $\checkmark$ & $\checkmark$ & $\checkmark$ & $\checkmark$ & $\checkmark$ & $\checkmark$ \\
\hline & Goal $D_{k}$ & $\checkmark$ & 0 & $\checkmark$ & $\checkmark$ & 0 & $\checkmark$ \\
\hline & Goal $F_{k}$ & $\checkmark$ & $\checkmark$ & 0 & 0 & $\checkmark$ & $\checkmark$ \\
\hline & Goal $H_{k}$ & $\checkmark$ & $\checkmark$ & $\checkmark$ & $\checkmark$ & $\checkmark$ & $\checkmark$ \\
\hline \multirow{4}{*}{$\mathrm{H} 3$} & Goal $A_{e}$ & $\checkmark$ & $\checkmark$ & $\checkmark$ & $\checkmark$ & $\checkmark$ & $\checkmark$ \\
\hline & Goal $C_{e}$ & $\checkmark$ & $\checkmark$ & $\checkmark$ & $\checkmark$ & $\checkmark$ & $\checkmark$ \\
\hline & Goal $E_{e}$ & $\checkmark$ & 0 & 0 & 0 & 0 & 0 \\
\hline & Goal $G_{e}$ & $\checkmark$ & $\checkmark$ & $\checkmark$ & $\checkmark$ & $\checkmark$ & $\checkmark$ \\
\hline \multirow{4}{*}{$\mathrm{H} 4$} & Goal $B_{e}$ & $\checkmark$ & 0 & $\checkmark$ & $\checkmark$ & $\checkmark$ & $\checkmark$ \\
\hline & Goal $D_{e}$ & $\checkmark$ & 0 & $\checkmark$ & $\checkmark$ & 0 & $\checkmark$ \\
\hline & Goal $F_{e}$ & $\checkmark$ & $\checkmark$ & 0 & 0 & $\checkmark$ & $\checkmark$ \\
\hline & Goal $H_{e}$ & $\checkmark$ & $\checkmark$ & 0 & $\checkmark$ & 0 & $\checkmark$ \\
\hline
\end{tabular}

Hypothesis H3 is confirmed: All PPPs succeed in stimulating and organizing the participation of relevant actors (goal $A_{e}$ ) and in providing physical infrastructure to a degree, although only partially concerning financial infrastructure (goal $G_{e}$ ). Goals $C_{e}$ and $E_{e}$ are addressed in all PPPs, too, although differences across PPPs exist with regard to the way how these goals are addressed. PPPs therefore generally are capable of addressing the presence dimension of entrepreneurial systemic functions of an RIS.

Hypothesis H4 is partially supported by empirical evidence: All PPPs provide an opportunity for partners to articulate available competences and resources (goal $B_{e}$ ), and the majority of PPPs extend partners' capacities to exert influence over the partnership's operating activities (goal $D_{e}$ ). Concerning goal $F_{e}$ sector-related differences of the stringency of institutions across PPPs have been found. The impact on the quality of infrastructure through PPPs (goal $H_{e}$ ) varies across regions; not all aspects of infrastructure are targeted by PPPs.

Thus we find that all PPPs are able to ensure the presence of relevant structural elements within a RIS with regard to both knowledge-related and entrepreneurial activities. The result is less clear concerning quality aspects as PPPs' structural diversity allows for considerable qualitative variations of RIS characteristics across regions and industries; therefore, the qualitative (capability) dimension's accomplishments vary across goals, sectors and regions. PPPs tend to be gradually more suitable for targeting quality aspects of knowledge-related than for targeting entrepreneurial regional innovation activity. Particularly in non-profit forms of cooperation, PPPs in the field of RIP are primarily focused on knowledge-related activities in order to enhance 
innovation processes. Entrepreneurial activities are also present since joint generation of innovative ideas offers attractive business incentives for private stakeholders by facilitating commercial embracing and exploitation of emerging innovation.

Differences along the knowledge-related dimension of systemic goals of RIP appear to be industry-specific. The learning rationale and the strength of relationships between participating actors differ across sectors: in life science PPPs' learning practices appear to be easily adaptable to existing operational and innovation patterns of partners; in ICT-based PPPs more effort is devoted to workforce up-skilling than PPPs in the other sectors. Differences along the entrepreneurial dimension of systemic goals of RIP appear to be largely region-specific. The institutional framework seems to be rather contextdependent, and the levels of regional policy-coordination efficiency might vary across (types of) regions. The economic diversification in large and highly developed Sydsverige intensifies redistributive conflicts among a multitude of actors, while in peripheral Övre Norrland's RIP only a smaller number of actors is present, and PPPs therefore tend to exert more influence in regional policy-making.

Our empirical analysis relates to industries with analytical and synthetic knowledge bases (Asheim \& Coenen, 2005), and to regions that are part of a nation which is among Europe's innovation leaders. Further research, therefore, should be extended to more varieties of regional contexts and industries in order to capture an even broader spectrum of PPP-use in RIP. As proximity issues are a key element for understanding the innovation process (Boschma, 2005) future research should also focus on operationalizing proximity linkages within the PPP context. Last but not least research on the use of PPPs as a systemic instrument of regional innovation policy would benefit from solving the issue of performance measurement of PPPs in order to allow comparing the effectiveness and efficiency of PPP with other instruments of regional innovation policy. 
Public Private Partnerships as a Systemic Instrument of Governance in Regional Innovation Policy

Dr. Iryna Kristensen is research fellow at the Nordic Center for Spatial Development (Nordregio) in Stockholm. Before she was affiliated to SCEUS - the Salzburg Centre for European Union Studies at the University of Salzburg. She graduated with a PhD from Salzburg University in 2015 on the topic of "Public-Private Partnerships and Regional Innovation Policy". Her current research focuses on questions related to regional innovation development and smart specialization in the Nordic Region.

Dr. Walter Scherrer is associate professor of economics and public finance at the Department of Economics and Social Science at University of Salzburg and academic director of postgraduate management studies at the Business School of Salzburg University. His current research focuses on regional economic policy (regional innovation policy in particular), on economic aspects of innovation (especially on long term analysis of innovation), and on public private partnerships. 


\section{References}

Asheim, B., \& Coenen, L. (2005). Knowledge bases and regional innovation systems: Comparing Nordic clusters. Research Policy, 34(8), 1173-1190. DOI: $10.1016 /$ j.respol.2005.03.013

Asheim, B., Smith L. H., \& Oughton, C. (2011). Regional Innovation Systems: Theory, Empirics and Policy. Regional Studies, 45(7), 875-891. DOI: $10.1080 / 00343404.2011 .596701$

Baras, J. S., Marti, P., Rodden, T., \& Stenius, P. (2003). The Competence Centers Programme. Third International Evaluation. Group 1 (8 Centers). Stockholm: Vinnova - Swedish Agency for Innovation Systems/Verket för Innovationssystem.

Boschma, R. (2005). Proximity and innovation: A critical assessment. Regional Studies, 39(1), 61-74. DOI: 10.1080/0034340052000320887

Brinkerhoff, D. W., \& Brinkerhoff, J. M. (2011). Public-private partnerships: Perspectives on purposes, publicness, and good governance. Public Administration \& Development, 31(1), 2-14. DOI: 10.1002/pad.584

Cooke, P. (2002). Knowledge economies: Clusters, learning and co-operative advantage. Oxford: Routledge. DOI: 10.4324/9780203445402

Cooke, P., \& Morgan, K. (1994). The Creative Milieu: A Regional Perspective on Innovation. In M. Dodgson \& R. Rothwell (Eds.), The Handbook of Industrial Innovation (pp. 25-32). Cheltenham: Edward Elgar.

Edquist, C. (1997). Systems of Innovation Approaches: Their Emergence and Characteristics. In C. Edquist (Ed.), Systems of Innovation: Technologies, Institutions and Organizations (1-29). London: Pinter.

Edquist, C., \& Johnson, B. (1997). Institutions and Organizations in Systems of Innovation. In C. Edquist (Ed.), Systems of Innovation: Technologies, Institutions and Organizations (41-60). London: Pinter.

European Commission. (2011). Regional Biotechnology: Establishing a methodology and performance indicators for assessing bioclusters and bioregions relevant to the KBBE area. Brussels: Directorate-General for Research.

European Commission. (2014). Regional Innovation Scoreboard 2014. Brussels: Directorate-General Enterprise and Industry.

Fogelberg, H., \& Thorpenberg, S. (2012). Regional innovation policy and publicprivate partnership: The case of Triple Helix Arenas in Western Sweden. Science and Public Policy, 39(3), 347-356. DOI: 10.1093/scipol/scs023

Galli, R., \& Teubal, M. (2002). Paradigmatic Shifts in National Innovation Systems. In C. Edquist (Ed.), Systems of Innovation: Technologies, Institutions and Organizations (342-347). London: Pinter.

Gertler, M. S. (2003). Tacit knowledge and the economic geography of context, or the undefinable tacitness of being (there). Journal of Economic Geography, 3(1), 75-99. DOI: $10.1093 / \mathrm{jeg} / 3.1 .75$

Hagedoorn, J., Link, A. N., \& Vonortas, N. (2000). Research partnerships. Research Policy, 29(4-5), 567-586. DOI: 10.1016/S0048-7333(99)00090-6

Isaksen, A. (2001). Building regional innovation systems: Is endogenous industrial development possible in the global economy? Canadian Journal of Regional Studies, 24(1), 101-120.

Karlsson, C. (Ed.). (2008). Handbook of Research on Innovation and Clusters. Cheltenham: Edward Elgar. DOI: 10.4337/9781848445079

Kristensen, I., McQuaid, R. W., \& Scherrer, W. (2016) Public Private Partnership as an Instrument of Innovation Policy. in U. Hilpert (Ed.), Handbook of Politics and Technology (pp. 249-261). Oxford: Routledge. 
Public Private Partnerships as a Systemic Instrument of Governance in Regional Innovation Policy

Leydesdorff, L., \& Zawdie, G. (2010). The triple helix perspective of innovation systems. Technology Analysis \& Strategic Management, 22(7), 789-804.

DOI: 10.1080/09537325.2010.511142

Lundvall, B.-A. (Ed.). (1992). National Systems of Innovation: Towards a theory of innovation and interactive learning. London: Pinter.

McQuaid, R. W. (2000). The Theory of Partnerships: Why have Partnerships. In S. P. Osborne (Ed.), Managing public-private partnerships for public services: An international perspective (9-35). Oxford: Routledge.

McQuaid, R. W., \& Scherrer, W. (2008). Public Private Partnership in the European Union: Experiences in the UK, Germany, and Austria. Uprava - International Public Administration Review, 6(2), 7-31.

McQuaid, R. W., \& Scherrer, W. (2010). Changing reasons for public private partnerships. Public Money and Management, 30(1), 27-39.

DOI: 10.1080/09540960903492331

Mrak, M. (2006). Institutionalization of Public-Private-Partnership: Global Experiences and the Basic Outlines of a Proposal for Slovenia. UpravaInternational Public Administration Review, 4(1), 91-103.

Nelson, R. R., \& Winter, S. G. (1977). In search of a useful theory of innovation. Research Policy, 6(1), 36-76. DOI: 10.1016/0048-7333(77)90029-4

OECD. (2004). OECD Science, Technology and Industry Outlook 2004. Paris: OECD.

OECD. (2008). Public-Private Partnerships. Paris: OECD.

OECD. (2010). Territorial Reviews: Sweden. Paris: OECD.

OECD. (2011). Regions and Innovation Policy, OECD Reviews of Regional Innovation. Paris: OECD.

Saldaña, J. (2009). The Coding Manual for Qualitative Researchers. Los Angeles: SAGE.

SCB. (2012). Arsbok för Sveriges kommuner. Statistiska centralbyrån. Stockholm: Swedish Central Statistical Office.

Silva, M. R., \& Rodriguez, H. (2005). Public-private partnerships and the Promotion of Collective Entrepreneurship (FEP Working Papers 172). University of Porto.

Smits, R., \& Kuhlmann, S. (2004). The rise of systemic instruments in innovation policy. International Journal of Foresight and Innovation Policy , 1(1-2), 4-32. DOI: $10.1504 /$ IJFIP.2004.004621

Švigelj, M., \& Horvatin, N. (2013). The Impact of the Financial and Economic Crisis on Public Private Partnerships. International Public Administration Review, 11(2), 77-89. DOI: 10.17573/ipar.2013.2.a04

Vinnova. (2009). First Evaluation of the Second, Third and Fourth Round of Vinnova Vinn Excellence Centers. Stockholm: Vinnova - Swedish Agency for Innovation Systems/Verket för Innovationssystem.

Vinnova. (2010). Evaluation of the Industry Excellence Centre (INDEC) System Design on Silicon (SoS), Lund University. Stockholm: Vinnova - Swedish Agency for Innovation Systems/Verket för Innovationssystem.

Weihe, G., Höjlund, S., Bouwhof Holljen, E. T., Petersen, O.H., Vrankbaek, C., \& Ladenburg J. (2011). Strategic use of public-private cooperation in the Nordic region. Copenhagen: Nordic Council of Ministers.

Wieczorek, A., \& Hekkert, M. (2012). Systemic instruments for systemic innovation problems: A framework for policy makers and innovation scholars. Science and Public Policy, 39(1), 74-87. DOI: 10.1093/scipol/scr008

Wolfe, D. (1999). Harnessing the region: Changing perspectives on innovation policy in Ontario. In T. J. Barnes \& M. S. Gertler (Eds). The New Industrial Geography: Regions, regulation and institutions (127-155). Oxford: Routledge. 


\section{Appendix 1: Description of Cases}

\begin{tabular}{|c|c|c|}
\hline Region & Case & Description \\
\hline \multirow{3}{*}{ 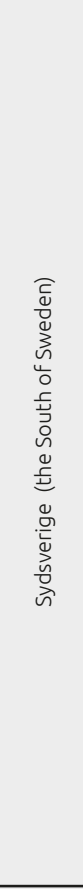 } & 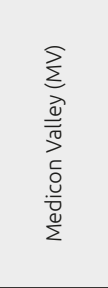 & $\begin{array}{l}\text { MV is a Danish-Swedish biotech cluster, specializing in five therapeutic areas i.e. diabetes/ } \\
\text { metabolism, neuroscience, cancer, inflammation and allergy, comprises the capital city, } \\
\text { Copenhagen, and the Själland region on the Danish side, and Skåne region on the Swedish } \\
\text { side (the cross-border Ôresund region). MV has currently } 250 \text { paying members including } \\
\text { universities, hospitals, regional governments and life science companies (including the } \\
\text { major pharmaceutical companies in the region i.e. Novo Nordisk, Lundbeck and Astra- } \\
\text { Zeneca) representing the triple helix structure in the region. At the cluster organization } \\
\text { level, public-private cooperation is well established implying that financial and performance } \\
\text { consequences of a risk are distributed among public and private partners; however, as there } \\
\text { are complex interactions with both local and international research groups, knowledge } \\
\text { networks in life science industry (particularly of major companies) the risk distribution as well } \\
\text { as the degree of financial and performance risk will vary across projects. }\end{array}$ \\
\hline & 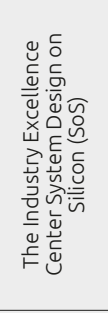 & $\begin{array}{l}\text { SoS was launched in } 2008 \text { at Lund University by the Swedish Innovation Agency (Vinnova) as } \\
\text { a } 10 \text { year project, operating under the umbrella program called 'Industry Excellence Center } \\
\text { Program', to contribute to the development of novel system solutions on silicon for wireless } \\
\text { communication devices (Vinnova 2010). SoS builds up on a long-term commitment and } \\
\text { research interest from one of the major ICT players i.e. Ericsson. The main mission of the } \\
\text { established Center is to strengthen collaborative links between industry and university with } \\
\text { the intention of upgrading knowledge and competence necessary to carry out high-quality } \\
\text { and industry-relevant research. These favourable framework conditions have offered a } \\
\text { platform for an open dialogue between partners, bringing basic research closer to industrial } \\
\text { needs and thereby reducing the risk of project failure i.e. performance risk is shared between } \\
\text { public and private partners (Vinnova 2010). However, a certain financial risk is still present } \\
\text { if one of the multinational enterprises decides to withdraw from the partnership, putting a } \\
\text { financial restraint on research activities for both public and private partners. }\end{array}$ \\
\hline & 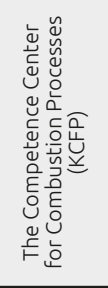 & $\begin{array}{l}\text { KCFP started in } 1995 \text { under the national umbrella program called the 'Swedish Competence } \\
\text { Centers Program' with the purpose to build a better understanding of the combustion } \\
\text { process in internal combustion engines. Strong connections with Sweden's automotive, } \\
\text { stationary power and heavy vehicle industry that go back to the big restart of combustion } \\
\text { activities in Lund in the beginning of the } 1990 \text { s (prior to the establishment of KCFP), laid } \\
\text { the basis for the center's cross-disciplinary interaction between various public and private } \\
\text { partners (Baras et al. 2003). The scope of the Center's operation has created an enabling } \\
\text { environment also for the participation of SMEs (Swedish Energy Agency 2009) that may serve } \\
\text { as potential suppliers to large companies (e.g. valve technology promoted by the Center to } \\
\text { engine OEMs). Partners are exposed to a low risk of not reaching the full research potential } \\
\text { as well as to some level of financial risk as funding come in equal shares from public and } \\
\text { private stakeholders. }\end{array}$ \\
\hline \multirow{3}{*}{ 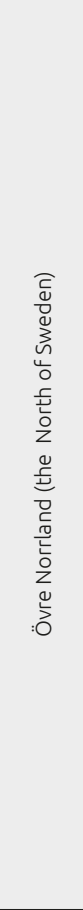 } & 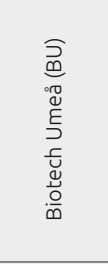 & $\begin{array}{l}\text { BU is a life-science cluster in the north of Sweden that is currently functioning under the } \\
\text { umbrella of Uminova Innovation - Business Incubator and Technology Transfer Office - to } \\
\text { support growth of the biotech and medical technology industry in the region particularly in } \\
\text { the areas of infectious disease research, plant and forest biotechnology, the nervous system, } \\
\text { metabolic diseases, medical technology and diagnostics. As an emerging cluster, BU lacks a } \\
\text { broad industrial base, and its potential for collaboration with partners from outside is limited; } \\
\text { therefore its activities are primarily directed towards creating spin-offs rather than strategic } \\
\text { research and product development (European Commission 2011). However, at the individual } \\
\text { level, cluster stakeholders (companies and universities) are quite externally-oriented and } \\
\text { open for R\&D activities and business partnerships with partners outside the cluster where } \\
\text { financial and performance risks are shared between public and private partners. }\end{array}$ \\
\hline & 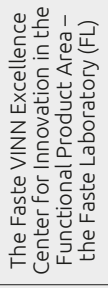 & $\begin{array}{l}\text { In } 2007 \text { the FL started at Luleå University of Technology under the national 'VINN Excellence } \\
\text { Center Program' aiming to enhance the interaction between research and industry towards } \\
\text { producing tangible economic benefits and innovation. Collaborative efforts of a PPP are } \\
\text { directed at the alignment of research agenda with shared industrial needs of private partners } \\
\text { with the purpose of contributing to sustainable economic growth (Vinnova 2009). Some } \\
\text { of the private partners e.g. Loussavaara-Kiirunavara AB (LKAB) have long-standing links } \\
\text { with the Luleå University of Technology providing a solid foundation of mutual trust and } \\
\text { understanding that the current Center can build upon (ibid). ). However, failure to meet } \\
\text { the planned performance level according to the submitted program, which in turn may } \\
\text { jeopardize future cash flow (every second year VINNOVA evaluates work and research } \\
\text { progress and makes decision whether or not to grant funding for another year) exposes } \\
\text { partners to a certain degree of shared financial and performance risk. }\end{array}$ \\
\hline & 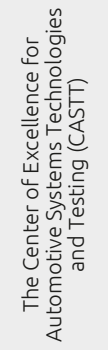 & $\begin{array}{l}\text { CASTT was founded by Luleå University of Technology in } 2005 \text { with the purpose to support } \\
\text { the automotive industry in the north of Sweden. The initiative came from the national } \\
\text { government, yet not as a formal request but more like guidance in the form of a 'press } \\
\text { release' stating that the government will allot a certain amount of money for the university } \\
\text { with the purpose to support winter test automotive area in the north of Sweden. However, } \\
\text { funding is currently only limited to ERDF and to financial contributions from VINNOVA. } \\
\text { Private partners include automotive testing companies, which are predominantly SMEs } \\
\text { (the largest one has a turnover of about } 40 \text { million euro), organized in the Swedish Proving } \\
\text { Ground Association (SPGA), automobile and component manufacturers; public partners } \\
\text { include the county, municipalities and Luleå University of Technology. Private partners bear } \\
\text { relatively low financial risk and comparatively high performance risk as regards hurting their } \\
\text { business reputation on the market if they are not able to deliver the agreed service. Public } \\
\text { partners are predominantly exposed to financial risk due to its strong dependence on public } \\
\text { funding whereas performance risk is significantly lower and is mainly related to supervisory } \\
\text { reporting (in order to raise funding for future activities). }\end{array}$ \\
\hline
\end{tabular}




\section{Javno-zasebno partnerstvo kot sistemski instrument upravljanja $\mathrm{v}$ regionalni inovacijski politiki}

V tem članku proučujemo, ali lahko javno-zasebno partnerstvo (JZP) deluje kot sistemski instrument regionalne inovacijske politike (RIP). JZP se je pojavil kot vse bolj znan in upoštevan instrument upravljanja v regionalni inovacijski politiki, še posebej pri raziskovanju in razvoju politik ter pri politikah grozdov. Potrebe po sodelovanju in tveganje sistemske napake so se povečevali zaradi vse večje heterogenosti inovacijskih procesov in agentov. Za JZP je značilno, da se osredotoča na graditev in krepitev povezav med akterji regionalnega inovacijskega sistema (RIS). Koncept JZP se v članku razume kot izraz sinergijske povezave med inovacijskimi agenti, izražene v sporazumu o sodelovanju institucij.

Študija analizira vzpostavljene kooperativne prakse med akterji javnega in zasebnega sektorja s sistemskega vidika v okviru štirih sistemskih problemov inovacijskega procesa. V skladu z literaturo razlikujemo: probleme akterjev, povezane z (ne)navzočnostjo ključnih akterjev in (ne)dostopnostjo ustreznih kompetenc za soočanje s tehnološkimi spremembami; interakcijske ali omrežne probleme, povezane s tehnološko zaostalostjo, ki ovira razvoj novih tehnologij, s pomanjkanjem komplementarnih zmogljivosti med agenti in ravnijo intenzivnosti interakcij; institucionalne probleme, povezane z množico splošnih navad, rutin, vzpostavljenih praks, pravil ali zakonov, ki ne utegnejo ustrezno podpirati inoviranja, ter infrastrukturne probleme, povezane z dostopnostjo in s kakovostjo fizične, izobraževalne in finančne infrastrukture. Vsak od naštetih sistemskih problemov ima tako kvantitativno kot kvalitativno dimenzijo. Poleg tega obsega vsak sistemski problem tudi podjetniško dimenzijo in z znanjem povezano dimenzijo za spodbujanje inoviranja. Če naj instrument inovacijske politike velja kot "sistemski" in sposoben izvajati sistemsko funkcijo, pa mora uspešno reševati vsaj enega od teh sistemskih problemov.

V članku poteka razprava o tem, katere sistemske funkcije se lahko uvajajo v regionalnih inovacijskih sistemih z uporabo JZP-ja kot gonila upravljanja v inovacijski politiki. Analiziramo šest primerov JZP-ja na področju RIP-a, v katerih so bile udeležene švedske občine in regionalne oblasti. Primeri se nanašajo tako na centralna kot periferna območja države, izhajajo iz treh industrijskih panog (avtomobilska industrija, informacijska tehnologija, bioznanost) z različnimi bazami znanja. Domnevamo, da je JZP primeren politični instrument za doseganje sistemskih ciljev RIP-a ter spodbujanje razvoja znanja in podjetniških aktivnosti znotraj RIS-a.

Analiza večinoma potrjuje naše hipoteze. Ugotavljamo, da lahko vsi primeri JZP-ja zagotovijo prisotnost relevantnih strukturnih elementov v RIS-u, 
tako aktivnosti, povezane z znanjem, kot podjetniške aktivnosti. Rezultat je manj jasen pri vidikih kakovosti, kajti strukturna raznolikost JZP-jev dopušča precejšnje kakovostne razlike značilnosti RIS-a v različnih regijah in industrijskih panogah. Pri JZP-jih se postopno pokaže, da so bolj primerni za lotevanje vidikov kakovosti sistemskih funkcij, povezanih z znanjem, kot za podjetniške funkcije regionalne inovacijske aktivnosti. Videti je, da so razlike pri dimenziji sistemskih ciljev RIP-a, povezanih z znanjem, specifične glede na industrijsko panogo. Logika učenja in čvrstost odnosov med sodelujočimi akterji se razlikujeta po sektorjih: v panogi bioznanosti se učenje zlahka prilagaja obstoječim operativnim in inovacijskim vzorcem partnerjev; v JZP-jih v panogi informacijske tehnologije pa je usposabljanju delovne sile namenjenih več prizadevanj kot v JZP-jih v drugih sektorjih. Razlike pri podjetniški dimenziji sistemskih ciljev RIP-a so pretežno odvisne od regije. Institucionalni okvir je bolj odvisen od konteksta, medtem ko se raven učinkovitosti regionalne politične koordinacije razlikuje glede na tip regije. Ekonomska diverzifikacija na velikih in visoko razvitih centralnih območjih povečuje intenzivnost konfliktov redistribucije med množico akterjev, medtem ko je v regionalni inovacijski politiki perifernih območij navzoče zgolj majhno število akterjev, zato imajo JZP-ji večji vpliv pri oblikovanju regionalne politike. 